\section{Reading electrocardiograms}

Metaphors are easy. What it isn't: no fingertip sworls, so the police aren't interested;

no long lines or abrupt breaks

like palm-reading;

no fuzzy snowstorm screen like a crystal ball;

no crazy QRS dowsing. No one can even tell

that the heart is beating: the lights may be on,

that's all. You need a pulse for that. You need more than chicken scratch, and what of the exploring heart, the intrepid muscle with a wandering baseline? No habla anglais. Ne parle pas.

What it is: a detective story. The private dicks are part of it. There is a gravedigger shovelling the Q wave's six feet, the long plot of a pause. It is a history: grizzled, from a Grizzly Adams.

But in the end it is an ocean, an ocean of waveforms,

an ocean that stretches across

the basin of a life.

Each feeler $\mathrm{P}, \mathrm{P}$ of

reconnaissance, $\mathrm{P}$ of preceding, leads to the enormous yes of a don't-give-me-a complex, then the billowing blanket of a ST segment

sloping up or down depending on bed angle.

Bedside, I peer at the tracing

and think lifestyle modification, lifestyle modification, what every heart needs

is the amplitude of truth. But I'm not looking for truth.

I'm looking for closed-mouth moments and the wave of goodbye, goodbye, which the police would be interested in, there is an order to stay within the city,

but it is unenforceable.

\section{Shane Neilson MD \\ Family physician \\ Guelph, Ontario}

\title{
An anatomy of malpractice
}

\author{
Madhouse: A Tragic Tale of Megalomania \\ and Modern Medicine \\ Andrew Scull \\ Yale University Press; 2005. \\ $360 \mathrm{pp}$, US $\$ 18.00$
}

$\mathrm{E}$ nthusiasts of psychiatric treatments have sometimes been accused of using attractive theories to shroud weak bodies of evidence. But when Dr. Henry Cotton, chief psychiatrist at the Trent State Mental Hospital in New Jersey from 1916 to 1933 relied on "focal sepsis" to justify his extreme treatments, a weak theory was used to cover one of the 20th century's major scandals.

The idea that hidden infection could cause madness had its roots in folk beliefs about auto-intoxication and seemed plausible to the public and to physicians who were eager to help the mentally ill.

Cotton claimed that new developments in bacteriology allowed him to identify infected patients (potential treatment responders), while modern surgery offered a definitive solution. Despite initial opposition, he moved forward with a campaign of aggressive diagnosis and surgery on hundreds of patients, removing teeth, tonsils, and sometimes sexual organs and colons (not necessarily in that order or restricted to a single procedure). Cotton reported an $85 \%$ cure rate for insanity in the 1920s, when his more circumspect colleagues could only wish for similar results. Few sounded the alarm when his outcomes were not replicated at other centres, and more than a decade went by before it was widely learned that Cotton's success rested on an unreported $30 \%$ mortality rate and an unrealistically broad definition of cure.

Andrew Scull's book shows how a theory-based intervention was promoted to the popular press, hospital administrators and politicians, all hoping for a fast, cost-effective solution to mental illness. $\mathrm{He}$ also illustrates how the needs of society's most vulnerable members were trumped by personal ambitions and professional loyalties reaching to the highest

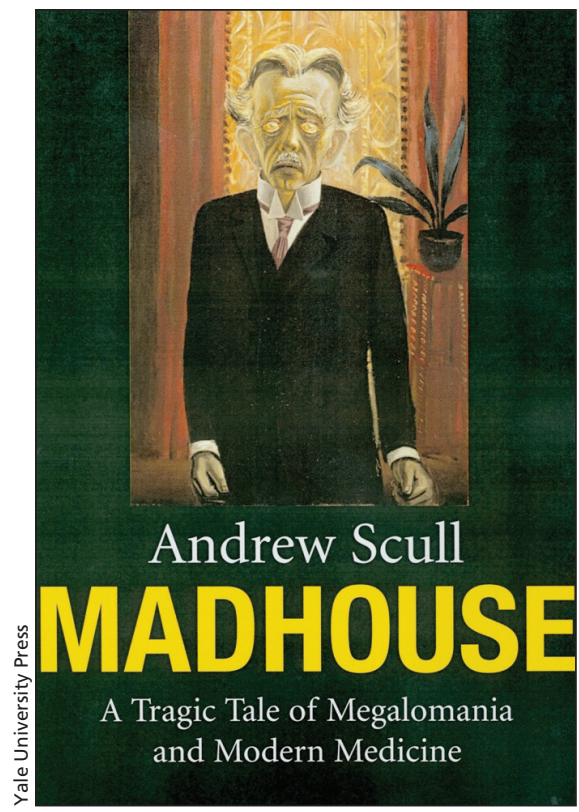

levels of American medicine, allowing the suppression of key scientific evidence for more than 10 years.

While some might argue that the case of Henry Cotton is a tragic, but isolated event, others may wonder why similar social forces appear to coalesce from time to time, catalyzing unfortunate situations and obscuring the basic ideals of the medical profession. Just as the horrors of Trent State in the 1920s and 1930s were winding down, the lobotomy craze, another tale of surgical enthusiasm with a charismatic self-promoter acting on a poorly tested theory, was beginning. Is the social organization of medicine partly to blame for malpractice? Will our current regulatory system protect us from interventions based on hope-infused theories rather than solid evidence? As one line of social enquiry into this complex problem, medical history appears to have more to offer than curiosities from the past. In the words of the great British historian William Stubbs, "the roots of the present lie deep in the past, and nothing in the past is dead to the man who learns how the present comes to be."

\section{Dorian Deshauer MD}

Associate Editor, Practice CMAJ 